\title{
Hepatitis B virus Genotyping Among Patients With Cirrhosis
}

\author{
Nastaran Ansari ${ }^{1, *}$; Manochehr Makvandi ${ }^{2}$; Ali Reza Samarbaf-Zadeh ${ }^{2}$ \\ ${ }^{1}$ Department of Virology, Tehran University of Medical Sciences, Tehran, IR Iran \\ ${ }^{2}$ Department of Virology, Faculty of Medicine, Jundishapur University of Medical Sciences, Ahvaz, IR Iran \\ *Corresponding author: Nastaran Ansari, Department of Virology, Tehran University of Medical Sciences, Tehran, IR Iran. Tel: +98-218112677819, E-mail: ansarinastaran@yahoo.com
}

Received: September 2, 2013; Revised: January 22, 2014; Accepted: March 15, 2014

\begin{abstract}
Background: Hepatitis B virus (HBV) infection is a worldwide public health problem. Nine HBV genotypes (A-I) have been already discovered. HBV genotypes are important both in the clinical manifestation of disease and treatment response. Moreover, HBV DNA without HBs (Hepatitis B surface)-antigenemia was detected in some patients with chronic hepatitis (occult hepatitis). There is little information about $\mathrm{HBV}$ genotypes and its relation to occult infection despite the importance of this infection in Khuzestan Province.

Objectives: This study aimed to determine both occult hepatitis B infection and HBV genotypes among cirrhotic patients.

Patients and Methods: Thirty-eight patients with liver cirrhosis, including 11 (28.9\%) HBsAg-positive patients and 27 (71.1\%) patients with cryptogenic cirrhosis participated in this study. The mean age of the patients at the time of cirrhosis diagnosis was 54.85 years (range 26-75 years). All patients were anti-HCV and anti-HIV negative. For all the samples, the serological Enzyme-Linked Immunosorbent Assay (ELISA) was performed for $\mathrm{HBV}$ markers including $\mathrm{HBsAg}, \mathrm{HBcAb}, \mathrm{HBeAg}$, HBeAb tests. The common primer of S region of HBV was used for Nested PCR. The PCR products of the positive individuals were sequenced for genotyping and subtyping of HBV.

Results: Eleven (40.7\%) out of 27HBV cryptogenic cirrhosis and all11HBsAg-positive patients were positive for HBVDNA.The seroprevalences of Hepatitis B virus HBe antigen, anti-HBe and anti-HBc antibodies among the cryptogenic cirrhosis patients were 5 (18.5\%), 1 (3.7\%), and 5 (20.83), and among HBsAg-positive patients were 6 (54.5\%), 5 (45.5\%), and 7 (63.6\%), respectively.

Conclusions: In our study, only HBV genotype D was found among all the positive HBsAg and occult HBV infection. Moreover, high prevalence (40.7\%) of occult HBV infection was determined among patients suffered from cryptogenic cirrhosis.
\end{abstract}

Keywords:Hepatitis B virus; Cirrhosis; Genotyping Techniques; Occult

\section{Background}

Hepatitis B virus (HBV) infection may lead to a wide spectrum of liver diseases ranging from an asymptomatic carrier state to severe chronic hepatitis, cirrhosis, and hepatocellular carcinoma (HCC). HBV is a member of the Hepadnaviridae family and has a relaxed-circular, partially double stranded DNA genome of approximately 3200 nucleotides (1). About 2 billion people in the world have been infected by HBV, which 400 million are chronic carriers. Approximately 600000 deaths occur each year from complications, including fulminant HBV infection, cirrhosis and HCC (2). Cirrhosis occurs in 20\%-30\% of those with Hepatitis B virus (HBV) (3). HBV is classified into nine genotypes, A to I, based on an intragroup nucleotide divergence of up to $4 \%$ of the S-genome sequences or in $>8 \%$ of the entire genome sequences (4). Genotype A of Hepatitis B virus in America, genotypes A and D in Europe, genotypes B and C in Asia and genotypes A, D, E are common in Africa $(5,6)$. Genotype $C$ causes more severe liver disease than genotype $B$ and is associated with increased risk of cirrhosis $(7,8)$. Genotype D of hepatitis B is predominant in Iran $(4,5)$.

Occult HBV infection accelerates the progression of liv- er fibrosis, cirrhosis, and finally leading to HCC (2). Occult Hepatitis B virus (HBV) infection is defined as the presence of HBV DNA in the liver (with or without detectable HBV DNA in serum) for individuals with negative HBsAg $(9,10)$. Some studies suggested that presence of occult HBV could be associated with more severe liver damage, cirrhosis, and increased rate of hepatocellular carcinoma (11). In Iran HBV prevalence is $1.7 \%-5 \%$ depending on geographic region $(12,13)$. To our knowledge, no study has been ever carried out on the HBV genotype in Iranian cirrhosis patients. Taking into consideration that HBV infections are common in Iranian patients with cirrhosis, we have investigated the genotyping of HBV among these patients in south region of Iran. Moreover, there is little information about prevalence of occult HBV infection despite the significant importance of this infection in progression of chronic liver disease.

\section{Objectives}

This study aimed to identify both HBV genotypes in Iranian patients with cirrhosis and determine the prevalence of occult HBV in these patients.

Copyright (C) 2015, Ahvaz Jundishapur University of Medical Sciences. This is an open-access article distributed under the terms of the Creative Commons Attribution-NonCommercial 4.0 International License (http://creativecommons.org/licenses/by-nc/4.0/) which permits copy and redistribute the material just in noncommercial usages, provided the original work is properly cited. 
Ansari N et al.

\section{Patients and Methods}

\subsection{Subjects}

This study included 38 patients with cirrhosis attending the Imam Khomeini Hospital of Ahvaz. Cirrhosis of the liver was diagnosed by professors of gastroenterology. The serum samples from 11 (28.94\%) cirrhotic HBsAg-positive patients and 27 (71\%) samples from cryptogenic cirrhosis cases with negative HbsAg were collected during 2011-2012. Hospital records were used to verify age, sex, and virological items such as HBsAg, HIV type 1 (HIV-1) antibody, and hepatitis C virus (HCV) antibody. Twentyseven $(71 \%)$ of them were male and eleven $(28.94 \%)$ were female. The mean age of the patients at the time cirrhosis diagnosis was 51.92 years (range 26-75 years).

\subsection{Serological Markers}

serological markers of $\mathrm{HBV}$, including $\mathrm{HBs}$, anti-HBs, anti-HBe, HBe and anti-HBs, were measured by ELISA using an automatic enzyme detection system (Tecan, Swiss) and a commercial kit(DIA.PRO, Italy). The ELISA tests were carried out according to the manufacturers' protocols.

\subsection{DNA Extraction, Nested-PCR and Sequencing}

HBV DNA was extracted from the sera of patients using specimens with commercial kit (Roche, Germany). Two pairs of primers called, FHBS1, RHBS1, FHBS2, RHBS2 were used to perform nested PCR (14). Selected primers corresponded to the conserved regions among the different genotypes and surrounding regions that were heterogeneous among them, allowing the distinction of HBV genotypes. DNA from the HBV S gene was amplified using nested PCR. Primers for the first-round PCR were FHBS1, 5'-GAG TCT AGA CTC GTG GTG GAC TTC-3' (outer, sense) and RHBS1, 5'-AAA TKG CAC TAG TAA ACT GAG CCA-3' (outer, antisense), and the second-round primers were FHBS2, $5^{\prime}$-CGT GGT GGA CTT CTC TCA ATT TTC-3' (inner, sense) and RHBS2, 5'-GCC ARG AGA AAC GGR CTG AGG CCC-3' (outer, antisense). The primer positions in the HBV genome (strain HBVADW; GenBank accession number 00866) were as follows: HBS1F (positions 244 to 267), HBS2F (positions 255 to 278), HBS2R (positions 648 to 671), and HBS1R (positions 668 to 691). The final amplicon encompassed 417 nucleotides of the $S$ gene.

The reaction mixtures in step 1 and 2 are shown in Table 1. Amplification in both PCR rounds was subjected in the TC-3000 Thermal Cycler (Techne) with initial denaturation at $94^{\circ} \mathrm{C}$ for $20 \mathrm{~s}$, followed by 30 cycles of amplification: denaturation at $94{ }^{\circ} \mathrm{C}$ for 20 seconds, annealing at $56^{\circ} \mathrm{C}$ for 20 seconds and elongation at $72^{\circ} \mathrm{C}$ for 30 seconds, followed by final extension step at $72^{\circ} \mathrm{C}$ for 1 minute.

\subsection{Detection of PCR Product}

Ten microliter of the PCR product was electrophoresed in a $2 \%$ agarose gel made in Tris-acetated-EDTA (TAE) buffer, $\mathrm{pH}=8-8.5$, and observed by UV illumination after ethidium bromide $(10 \mathrm{mg} / \mathrm{L})$ staining. Forty microliter of the final PCR product was sequenced by ABI (Narges Genetics Laboratory) Ahvaz, Iran.

\subsection{Reference Sequences and Phylogenetic Analysis}

Sequences were genotyped by phylogenetic reconstructions using reference sequences from all HBV genotypes obtained from Gen Bank comprising of HBsAg region (S). Complete genomes where also obtained from GenBank and phylogenetic analyses were performed. All sequences were aligned using CLUSTAL W. Phylogenetic tree was constructed by the neighbor-joining (N-J) method (15) with the mid-point rooting option. To confirm the reliability of the phylogenetic tree, bootstrap resampling tests were carried out 1000 times. The accession numbers and country of the reported sequences were as following: genotype A, AB014370 from Japan, AB222707 from Uzbekistan, AF297621 from South Africa, EU410082 from the Philippines, and AB194951 from Cameroon; genotype B, AB073838 from Japan, AF121243 from Sweden, M54923 from Indonesia, AY167098 from Taiwan, X97850 from the UK; genotype C, AB014393 from Japan, AB222714 from Uzbekistan, X75665 from Sweden, X75656 from Polynesia, AB105172 from Hawaii, EU439009 from China; genotype D, AF043593 from Germany, and Z35716 from Poland, X80924. The analyses and calculated nucleotide differences within and between the isolated sequences were carried out by MEGA program, version 4 (16).

\subsection{Statistical Analysis}

Analysis of the data was performed with SPSS, version 16.0. The statistical analyses were evaluated by chi-square and Fisher exact tests. Data are expressed as median. $\mathrm{P}<$ 0.05 was considered significant.

\section{Results}

Among 27 patients with cryptogenic cirrhosis, DNA of virus was isolated in 11 (40.7\%) cases with negative $\mathrm{HbsAg}$ by nested PCR assay, whereas HBcIgG test in $4(36.4 \%)$ cases of them were positive and 6 (54.5\%) of them were negative for all markers. In $3(27.28 \%)$ of 11 patients with positive HBsAg, HBeAg, and HBeAb both tests were negative, but HBcIgG test of them were positive. Characteristics of all patients with liver cirrhosis and their serological markers are described in Table 2.

\begin{tabular}{lcc}
\hline Table 1. Reaction Mixtures in Step 1 and 2 & \\
\hline Materials, $\mu \mathbf{L}$ & Step 1 & Step 2 \\
\hline PCR Buffer $(\mathbf{1 0 X})$ & 2.5 & 5 \\
Primer FHBS1 $(\mathbf{1 0 0} \mathbf{~ p m o l} / \mu \mathbf{L})$ & 0.25 & 0.5 \\
Primer RHBS2 $(\mathbf{1 0 0} \mathbf{~ p m o l} / \mu \mathbf{L})$ & 0.25 & 0.5 \\
dNTP Mix $(\mathbf{1 0} \mathbf{~ M m )}$ & 0.5 & 1 \\
Taq DNA polymerase & 0.15 & 0.3 \\
Distilled Water & 20.35 & 40.7 \\
Template (DNA) & 2 & 2 \\
Total & 25 & 50 \\
\hline
\end{tabular}


Ansari N et al.

Table 2. Characteristics of Cirrhotic Patients and Their Serological Markers

\begin{tabular}{lcccccc}
\hline Cirrhotic patients & No. $(\%)$ & Gender (M/F) & Mean Age, $\mathbf{~}$ & HBcIgG +, No. $(\%)$ & HBeAg +, No. (\%) & HBeAb +, No. (\%) \\
\hline HBsAg + & $11(29)$ & $0.83(5 / 6)$ & 51.45 & $7(63.6)$ & $5(45.5)$ & $6(54.5)$ \\
Cryptogenic & $27(71)$ & $4.4(22 / 5)$ & 52.40 & $5(20.83)$ & $5(18.5)$ & $1(3.7)$ \\
Total & 38 & $2.45(27 / 11)$ & 51.92 & $12(34.28)$ & $10(26.3)$ & $7(18.4)$ \\
\hline
\end{tabular}

Figure 1. Phylogenetic Trees Based on Comparison of the S Region of Genome.

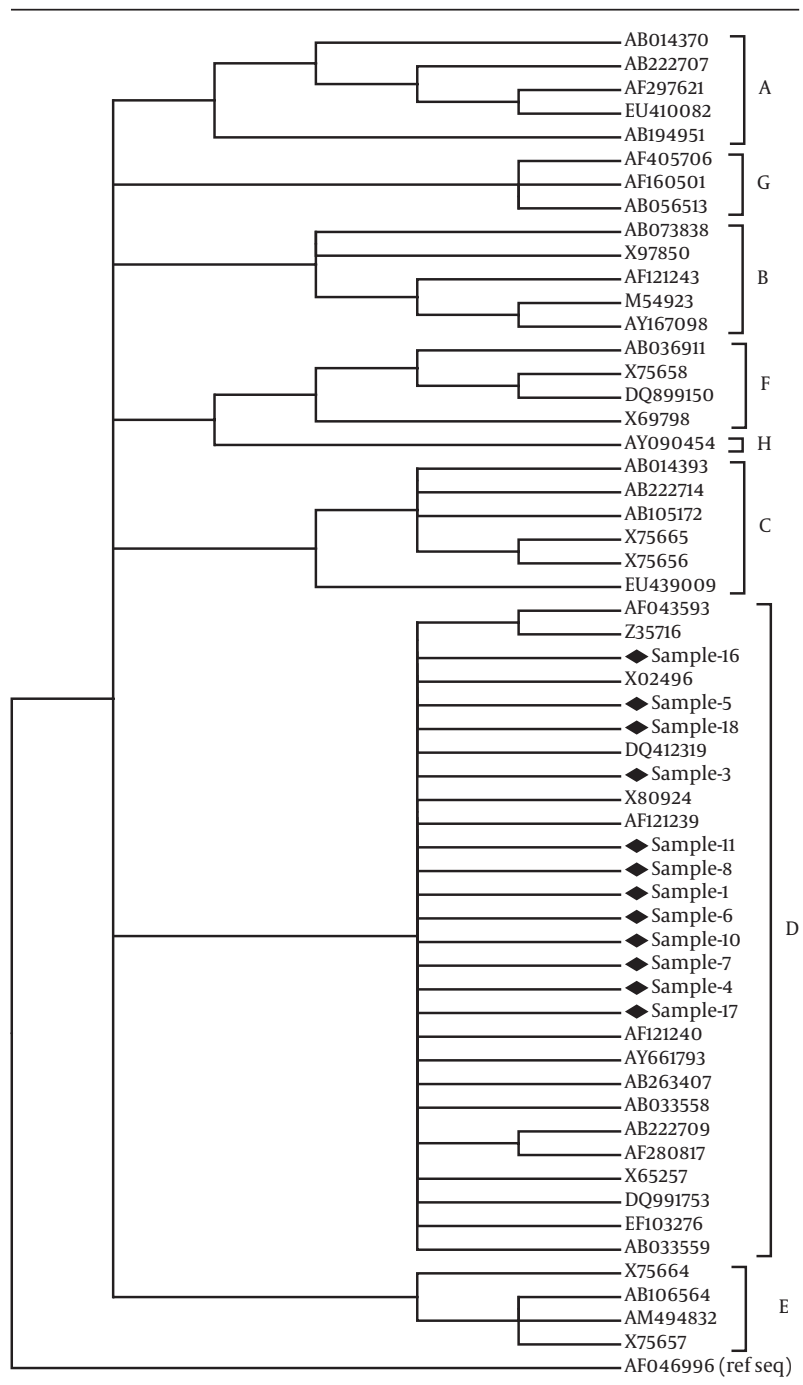

Iranian sequences determined in this study are indicated by $(\bullet)$ sign.

The specific genotype was investigated in 12 patients (among 19 PCR positive cirrhotic patients, $11 \mathrm{HBsAg}$ positive plus 8 cryptogenic) that their samples had a stronger bond in nested PCR assay. Genotype D was recognized in the 12 serum samples on the basis of sequence analysis of the $417 \mathrm{bp}$ fragment from $S$ gene of HBV. In the phylogenetic analysis with 44 genotype strains retrieved from the Gen Bank, all 11 sequences were clustered into genotype D (Figure 1).

\section{Discussion}

HBV genotypes have distinct geographical distributions, and have been reported to have various effects on the clinical course of the infected patients. Study the structure and various functions of each genotype assist significantly in the course of disease, symptoms, treatment response and response to vaccines and can be an effective aid in controlling and treating disease. The relationship between HBV genotypes and liver cirrhosis remains unclear. Some studies suggested that genotype $C$ had a higher risk of cirrhosis, whereas other studies indicated that the progression to cirrhosis did not differ among genotypes $\mathrm{B}$ and $C$ related chronic liver diseases (17-19). In a study by Aghakhani et al. in Pasteur Institute of Iran, all of patients with hepatocellular carcinoma were reported genotype D (5). Other studies in Iran revealed that the genotype D is dominant in our country $(12,20)$. Whereas using PCR-RFLP, Neisi et al. reported genotype B6 (4\%) as well as genotype D2 (92\%) in hemodialysis patients in Khuzestan province (21). But, relationship between HBV genotypes and liver cirrhosis has not been investigated in Iran so far.

In our study, HBV-D was the only detectable genotype in the both of positive HBsAg and cryptogenic cirrhotic patients with occult infection. In other words, no difference was found between the predominant genotypes in patients with cirrhosis and other patients with HBV infection in our area. Several other studies reported a correlation between HBV genotype and HBeAg clearance. Similarly, in our study, we found a lower prevalence of HBeAg among our patients with genotype D (25.7\%), suggesting that HBeAg clearance occurred at higher rates among patients with genotype D. However, further investigation is required to assess the role of genotype $\mathrm{D}$ on the regress of liver disease.

Occult HBV infection is characterized by positivity for HBV DNA in HBsAg-negative patients with or without serological markers of previous HBV infection (21). Occult HBV has associated with more advanced fibrosis/ cirrhosis (16). Cirrhosis is considered as an important risk factor for the development of $\operatorname{HCC}(22,23)$. Occult $\mathrm{HBV}$ infection prevalence in blood donors related to the prevalence of infection epidemiology, population composition and sensitivity of the methods used to investigate HBV-DNA. In areas with low prevalence of HBV, this amount is $0 \%-7.7 \%$ and in areas with high prevalence, a rate of $1.9 \%-12.7 \%$ has been reported in normal population. Sufian et al. in his study on blood donors in Arak (with low prevalence of $\mathrm{HBV}$ ) reported no case of occult hepatitis B infection (24). Also in another study by Joukar 
et al. on hemodialysis patients in Guilan, no cases of occult hepatitis B infection was found (25). But study on hemodialysis patients in Tehran Pasteur Institute showed that the rate of hepatitis B infection in these patients is 2.7\% (26). Gwak et al. has performed a study on chronic hemodialysis patients in Korea and he reported the rate of $0 \%(27)$.

Our study showed that $40.74 \%$ of the patients with cirrhosis had occult HBV infection. A similar investigation by Hassan et al. on patients with hepatocellular carcinoma in Egypt reported 22.5\% latent infection with hepatitis B (28). Likewise, a study was carried out by Hamkar and colleagues in Tehran on patients with chronic liver disease, which reported $22 \%$ of cases with occult HBV infection (29). Several studies in the Khuzestan Province indicated that high prevalence of HBV were found among different groups, including cirrhotic patients $(30,31)$. On the other hand, prevalence of cirrhosis in this region is high. These results have led to the discovery of more cases of the occult HBV infection in this community. Only genotype D was found among all the positive HBsAg and occult HBV infection. High prevalence (40.7\%) of occult HBV infection was determined among the cryptogenic cirrhotic patients. It is suggested that genotype D and persistent occult HBV infection may play an important role in the development of cirrhosis in our area.

\section{Acknowledgements}

This paper is based on thesis of Nastaran Ansari and its financial support was provided by Ahvaz Jundishapur University of Medical Sciences. The research was approved by Ethics Committee of Ahvaz Jundishapur University of Medical Sciences. The authors would like to thank Vice Chancellor for Research Affairs of Ahvaz Jundishapur University of Medical Sciences. We are grateful to all members of Virology Department and Narges diagnostic laboratories for their cooperation.

\section{Authors' Contributions}

Study concept and design: Manochehr Makvandi; drafting the manuscript: Nastaran Ansari; critical revision of the manuscript for important intellectual content: Manochehr Makvandi and Ali Reza Samarbaf-Zadeh; writing the manuscript: Nastaran Ansari.

\section{Funding/Support}

The study was financially supported by Ahvaz Jundishapur University of Medical Sciences (Registration No. 353), Ahvaz, Iran.

\section{References}

1. Awan Z, Idrees M, Amin I, Butt S, Afzal S, Akbar H, et al. Pattern and molecular epidemiology of Hepatitis B virus genotypes circulating in Pakistan. Infect Genet Evol. 2010;10(8):1242-6.

2. van Hemert FJ, Zaaijer HL, Berkhout B, Lukashov VV. Occult hepatitis B infection: an evolutionary scenario. Virol J. 2008;5:146.
3. Guirgis BS, Abbas RO, Azzazy HM. Hepatitis B virus genotyping: current methods and clinical implications. Int J Infect Dis. 2010;14(11):e941-53.

4. Mojiri A, Behzad-Behbahani A, Saberifirozi M, Ardabili M, Beheshti M, Rahsaz M, et al. Hepatitis B virus genotypes in southwest Iran: molecular, serological and clinical outcomes. World J Gastroenterol. 2008;14(10):1510-3.

5. Aghakhani A, Hamkar R, Zamani N, Eslamifar A, Banifazl M, Saadat A, et al. Hepatitis B virus genotype in Iranian patients with hepatocellular carcinoma. Int J Infect Dis. 2009;13(6):685-9.

6. Alfaresi M, Elkoush A, Alshehhi H, Alzaabi A, Islam A. Hepatitis B virus genotypes and precore and core mutants in UAE patients. Virol J. 2010;7:160.

7. Chan HL, Hui AY, Wong ML, Tse AM, Hung LC, Wong VW, et al. Genotype C Hepatitis B virus infection is associated with an increased risk of hepatocellular carcinoma. Gut. 2004;53(10):14948.

8. Yeh SH, Tsai CY, Kao JH, Liu CJ, Kuo TJ, Lin MW, et al. Quantification and genotyping of Hepatitis B virus in a single reaction by realtime PCR and melting curve analysis. J Hepatol. 2004;41(4):659-66.

9. Jahangirnezhad M, Hajiani E, Makvandi M, Jalali F. A study on risk factors of chronic hepatitis B carriers. Jundishapur J Microbiol. 2012;4(4):

10. Said ZN. An overview of occult Hepatitis B virus infection. World J Gastroenterol. 2011;17(15):1927-38.

11. Pollicino T, Squadrito G, Cerenzia G, Cacciola I, Raffa G, Craxi A, et al. Hepatitis B virus maintains its pro-oncogenic properties in the case of occult HBV infection. Gastroenterology. 2004;126(1):102-10

12. Alavian SM, Keyvani H, Rezai M, Ashayeri N, Sadeghi HM. Preliminary report of Hepatitis B virus genotype prevalence in Iran. World J Gastroenterol. 2006;12(32):5211-3.

13. Lisotti A, Grenci C, Caponi A, Roda E. Chronic hepatitis B in 2008. Dig Liver Dis. 2008;2(2):3-6.

14. Buti M, Rodriguez-Frias F, Jardi R, Esteban R. Hepatitis B virus genome variability and disease progression: the impact of pre-core mutants and HBV genotypes. J Clin Virol. 2005;34 Suppl 1:S79-82.

15. Saitou N, Nei M. The neighbor-joining method: a new method for reconstructing phylogenetic trees. Mol Biol Evol. 1987; 4(4):406-25

16. Zeng GB, Wen SJ, Wang ZH, Yan L, Sun J, Hou JL. A novel Hepatitis $B$ virus genotyping system by using restriction fragment length polymorphism patterns of S gene amplicons. World J Gastroenterol. 2004;10(21):3132-6.

17. Chen $\mathrm{CH}$, Hung $\mathrm{CH}$, Lee $\mathrm{CM}$, Hu TH, Wang JH, Wang JC, et al. Pre-S deletion and complex mutations of Hepatitis B virus related to advanced liver disease in HBeAg-negative patients. Gastroenterology. 2007;133(5):1466-74.

18. Chan HL, Tsang SW, Liew CT, Tse CH, Wong ML, Ching JY, et al. Viral genotype and Hepatitis B virus DNA levels are correlated with histological liver damage in HBeAg-negative chronic Hepatitis B virus infection. Am J Gastroenterol. 2002;97(2):406-12.

19. Sumi H, Yokosuka O, Seki N, Arai M, Imazeki F, Kurihara T, et al Influence of Hepatitis $\mathrm{B}$ virus genotypes on the progression of chronic type B liver disease. Hepatology. 2003;37(1):19-26.

20. Amini S, Hekmat S, Andalibi M, Abadi S. Subtypes of hepatitis B and associated factors in patients whit HBsAg referred to Tehran Medical Centers. Infect Dis. 2008;12(39):41-4

21. Neisi N, Makvandi M, Samarbaf-Zadeh AR. A study on genotypes of Hepatitis B virus among hemodialysis patients in Khuzestan province. JundishapurJ Microbiol. 2011;4(2):65-70.

22. Abdo AA, Al-Jarallah BM, Sanai FM, Hersi AS, Al-Swat K, Azzam NA et al. Hepatitis B genotypes: relation to clinical outcome in patients with chronic hepatitis B in Saudi Arabia. World J Gastroenterol. 2006;12(43):7019-24.

23. Stuyver L, De Gendt S, Van Geyt C, Zoulim F, Fried M, Schinazi RF, et al. A new genotype of Hepatitis B virus: complete genome and phylogenetic relatedness. J Gen Virol. 2000;81(Pt 1):67-74.

24. Sufian M, Izadi N, Aghakhani A. Prevalence of occult Hepatitis B virus infection in blood donors in Arak. Infect Dis. 2009;45:37-40.

25. Joukar F, Mansour-Ghanaei F, Besharati S, Khosh-Sorur M. Occult hepatitis B infection in a hemodialysis population in Guilan 


\section{Ansari N et al.}

province, northern Iran. Hemodial Int. 2012;16(2):294-7.

26. Negroa F. Management of chronic hepatitis B. Swiss Med Wkly. 2011;141:13264.

27. Gwak GY, Huh W, Lee DH, Min BH, Koh KC, Kim JJ, et al. Occult Hepatitis B virus infection in chronic hemodialysis patients in Korea. Hepatogastroenterology. 2008;55(86-87):1721-4.

28. Hassan ZK, Hafez MM, Mansor TM, Zekri AR. Occult HBV infection among Egyptian hepatocellular carcinoma patients. Virol J. 2011;8:90.

29. Hamkar R, Aghakhani A, Soufian S, Banifazl M, Ghavami N, Nadri $\mathrm{M}$, et al. Surface gene mutations of Hepatitis B virus among highrisk patients with occult Hepatitis B virus infection. Diagn Microbiol Infect Dis. 2010;66(3):285-91.

30. Ramezani A, Banifazl M, Kalantar E. Occult Hepatitis B virus infec- tion in hemodialysis patients. Infect Dis.;2009(44):27-30.

31. Hajiani E, Hashemi S, Masjedizadeh A. Seroepidemiology of Hepatitis B virus Infection in Khuzestan province, southwest of Iran. Hepat Mon. 2009;9(1):34-8. 